\title{
Lindcove REC: Developing citrus varieties resistant to huanglongbing disease
}

O

$f$ the many citrus varieties trialed at the Lindcove

Research and Extension Center (REC), one has been a

source of more than $\$ 14$ million in licensing revenue to

UC since 2006: the seedless, easy peel Tango mandarin, bred by Mikeal Roose, professor of genetics in the Department of Botany and Plant Sciences at UC Riverside, and UC Riverside researcher Tim Williams. Many millions of Tango trees have been planted worldwide, 4 million or so in California alone.

Three trees with inedible fruit at Lindcove REC, on the eastern edge of the San Joaquin Valley near Visalia, have Roose's attention now. They are 34-year-old trees, crosses of sweet orange (two) and Rangpur lime (one) with Eremocitrus glauca, the desert lime, a wild Australian citrus relative, which he had forgotten about until recently. It's a long shot, but they could lead to an even bigger winner than Tango has been - a citrus variety resistant to huanglongbing (HLB) disease, the greatest threat to California's citrus industry.

Mikeal Roose, professor of genetics at UC Riverside, whose program bred the seedless Tango mandarin, which has been a huge commercial success. Now he's working on a solution to the citrus industry's greatest challenge huanglongbing (HLB) disease.

Eremocitrus crosses at Lindcove REC are potentially promising in the pursuit of a genetic source of resistance to HLB. The fruit is golfball size and inedible. 


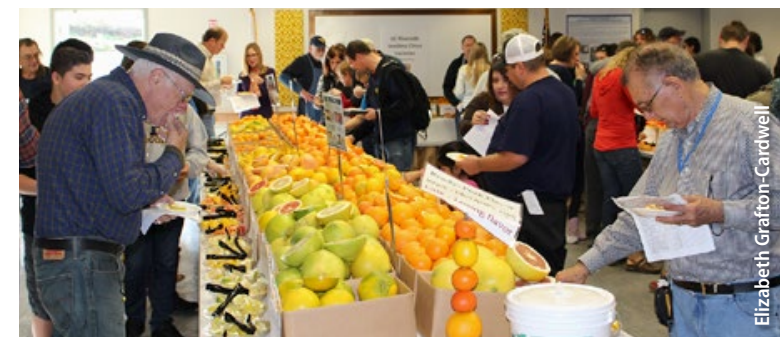

Lindcove REC's annual fruit display and tasting event in midDecember draws 200 to 300 people, including citrus growers making decisions about what to plant. HLB has halved citrus production in Florida; it is expected to arrive in commercial orchards in California within 5 years.

\section{Variety trials}

Lindcove plays a key role in citrus variety trials and in providing clean citrus propagation material for commercial releases. Ten Tango trees grow inside screened areas in the Foundation Block belonging to the Citrus Clonal Protection Program (CCPP), which provides pathogen-tested budwood from the mother trees to licensed nurseries that propagate trees for California citrus growers. No plantings of Tango are allowed in California unless the trees originate from these CCPP Foundation Block trees at Lindcove REC. Georgios Vidalakis, director of CCPP, when asked about their value, said: "I have repeatedly heard experienced members of our industry referring to Tango as the most influential citrus variety since the introduction of the Parent Washington navel orange in Riverside in 1873."

Tango is just one of several recent varieties that have come through Lindcove REC trials and achieved commercial success. Gold Nugget preceded Tango. KinnowLS is a more recent release. A low-seeded Lisbon lemon and a low-seeded Nova mandarin are in trials.

\section{HLB challenge}

Lindcove's citrus variety tastings are well attended by growers making planting decisions and seemingly determined to stay in the business in spite of HLB, a bacterial disease spread by a tiny flying insect, the Asian citrus psyllid. In just 10 years, HLB has cut citrus production in Florida by more than 50\%.

HLB has been found in residential citrus trees in Southern California but hasn't reached the Lindcove area or Central California's vast commercial orchards yet. Lindcove director Elizabeth GraftonCardwell expects the disease will arrive within 4 or 5 years. Lindcove,

California's main center for citrus field research and

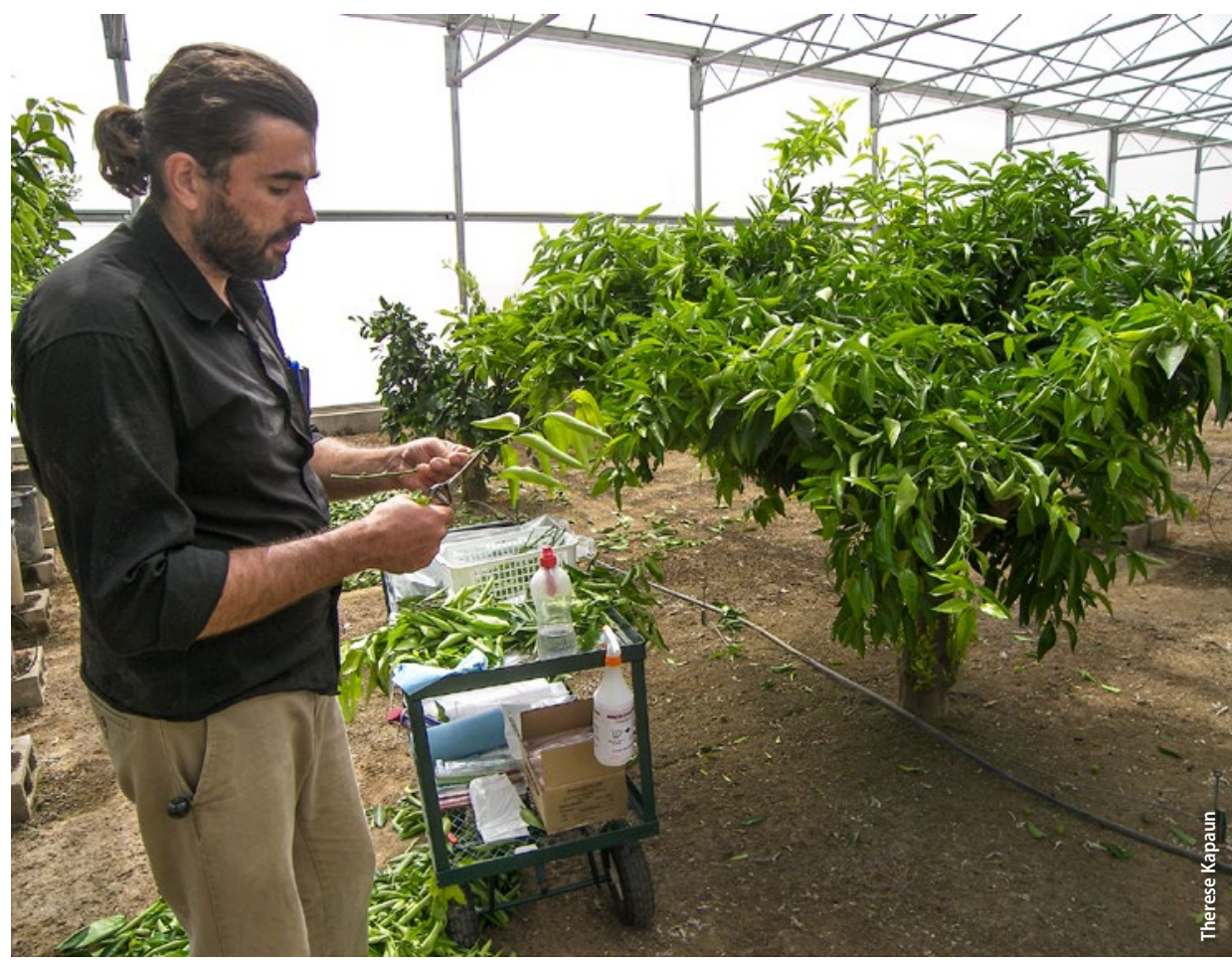

Researcher Rock Christiano collects budwood in the CCPP screen house at Lindcove REC. Pathogen-tested propagation material from here is distributed to licensed nurseries that produce trees for commercial growers.
Davis's research group at UC Davis has tested the use of a gas chromatograph at Lindcove REC to describe the profile of volatile organic compounds emitted by sick and healthy trees. At Lindcove, it was used to differentiate between trees infected with citrus tristeza virus and healthy trees. In Florida, the equipment shows promise for early detection of HLB infection.

In addition, ground at Lindcove is being prepared for two new studies. The CCPP has received industry and federal funding to introduce at least 50 citrus varieties that seem to be surviving the HLB epidemic in Florida research breeding blocks. These will be evaluated for their horticultural characteristics at Lindcove REC, and used by Roose and other scientists. The accessions include rootstocks, mandarins, sweet oranges, grapefruit and pummelos.

Another trial will assess mandarin productivity under a protective screen structure, which would keep out psyllids and HLB. Grafton-Cardwell is anticipat-

ing a "different style of growing citrus" in the future,
HLB is spread by tiny Asian citrus psyllids (actual size).

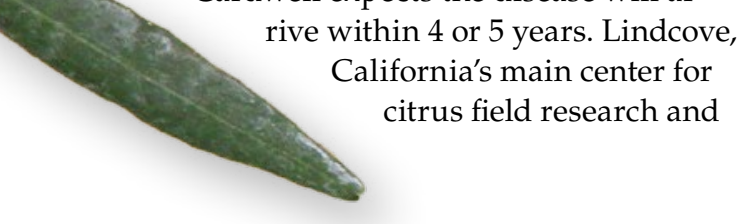


The Eremocitrus crosses at Lindcove are 34 years old and can be bred from right away. Crosses with mandarins are planned for this spring.

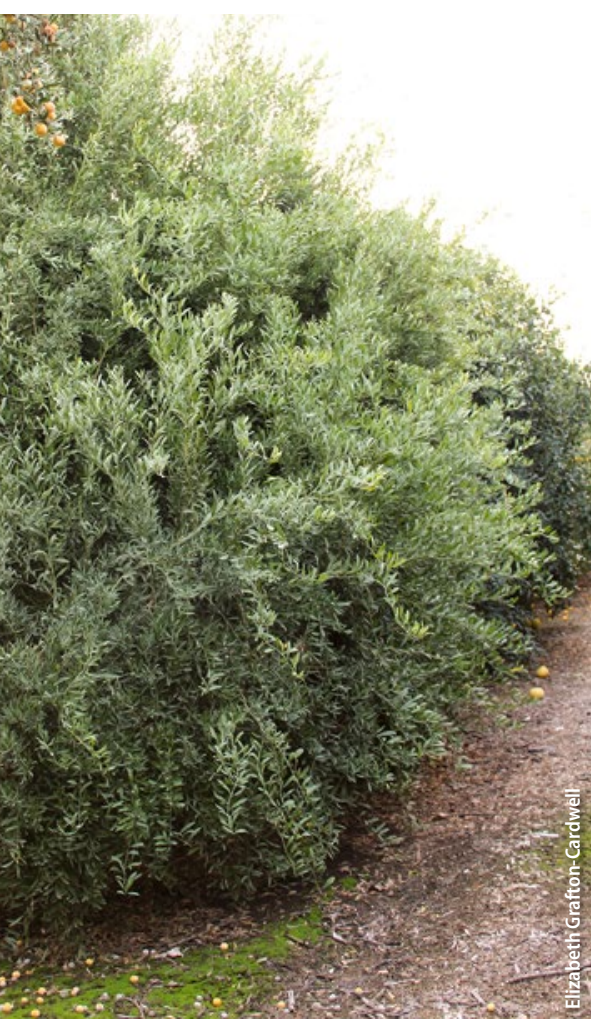

she says, perhaps under screens, perhaps as dwarfed trees in high-density plantings (a production method studied at Lindcove REC since 1998). Increasing the number of trees per acre might allow orchards to continue to be profitable after quickly detected HLBinfected trees are removed.

In Florida, where $80 \%$ of citrus trees or more are infected with HLB, citrus growers are struggling with orchard productivity. Yields are down around $40 \%$, and some growers are shifting to other crops or businesses. The California citrus industry has had the benefit of time to prepare for HLB, but Grafton-Cardwell stresses that there is an urgent need for the research community to develop new growing methods and new technologies to help growers adapt to the disease when it arrives.

\section{Breeding for HLB resistance}

Citrus breeding is a slow business, even if transgenic techniques are used. A genetically engineered (GE) juicing orange that has an anti-HLB gene taken from a variety of spinach is in trial in Florida. If successful and granted regulatory approval, the GE orange could be available commercially in 5 years, though growers will perhaps be risking planting citrus that some consumers would reject. At present, no transgenic trials are under way in California.

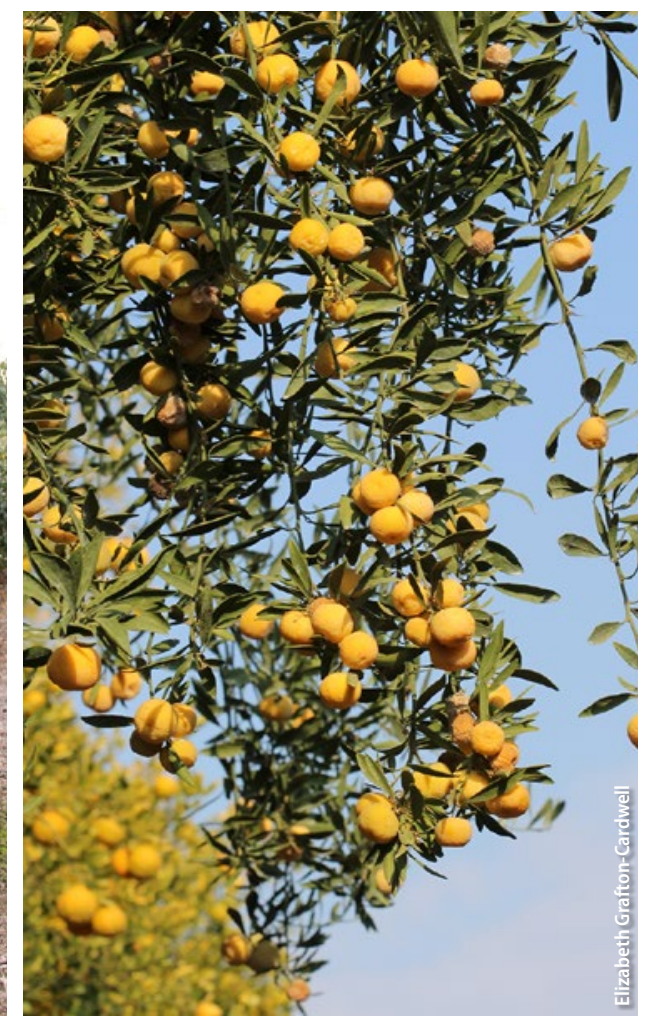

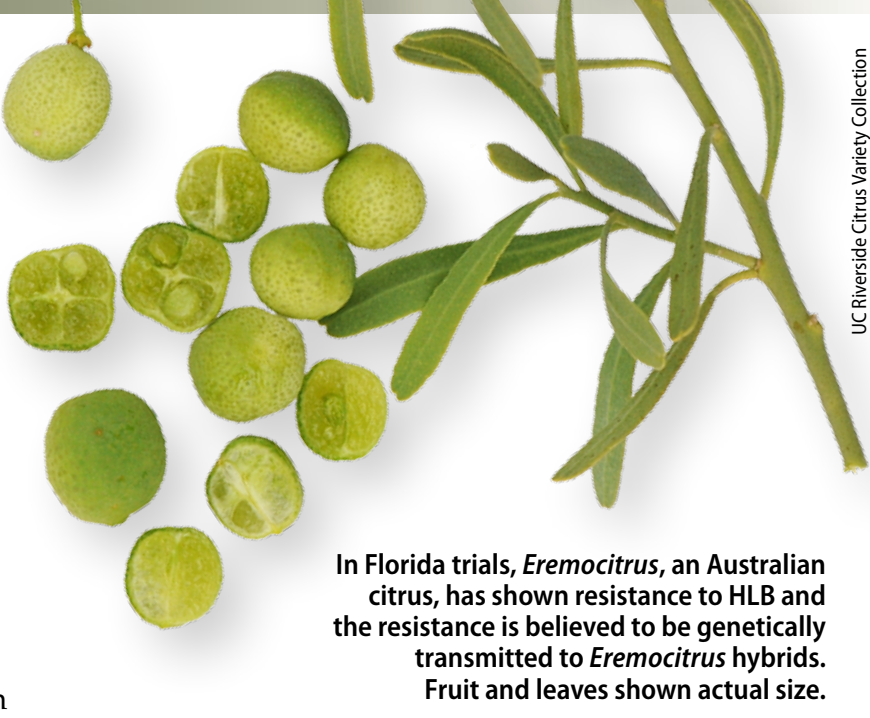

Roose acknowledges that HLB is likely to arrive in commercial orchards long before a resistant variety, GE or not, is available, and yet he is optimistic a solution can be found. He cites UC Riverside scientist Chandrika Ramadugu's project that tested, in Florida, HLB resistance in 100 California accessions of citrus and closely related genera from the National Clonal Germplasm Repository for Citrus and Dates. After years growing in orchards and greenhouses infected with HLB, an Australian citrus variety, Eremocitrus sp., was one of the few accessions discovered to be resistant to the HLB bacterium. And the resistance has been determined to be genetically transmitted to hybrids of Eremocitrus. However, it will be years before the juvenile trees of those Eremocitrus hybrids flower and produce pollen for crosses that might eventually produce a marketable variety.

Last year, puzzling over next steps, Roose remembered the collection of citrus trees he had inherited from his predecessors in the plant breeding program at UC Riverside and had been maintaining at Lindcove REC for 30 years. Among them are three Eremocitrus crosses, mature trees that may be carrying HLB resistance and can be bred from right away. He collected seed last year, and Ramadugu, his collaborator, plans to test these for HLB resistance, in containment facilities in California, as soon as the seedlings are large enough. They also plan to make crosses between these hybrids and mandarins this spring. If they can identify the genes that control resistance, there may be rapid methods to activate these genes in the citrus genome, causing it to become HLB resistant.

The trees are nondescript - glaucous leaves, weeping habit, fruit inedible and the size of a golf ball but Roose has a breeder's patience. "It's hard to know what the value of something is. The world changes, and something not valuable can become valuable," he says. Reminded of his and Williams's experiments with mandarin budwood in a medical irradiation unit years ago, he laughs. "Long shots can be quite important." CA

- Hazel White 